\title{
Differential Effect of Artemisinin Against Cancer Cell Lines
}

\author{
Mounir Tilaoui • Hassan Ait Mouse • \\ Abdeslam Jaafari $\cdot$ Abdelmajid Zyad
}

Received: 8 April 2014/Accepted: 19 May 2014/Published online: 5 June 2014

(C) The Author(s) 2014. This article is published with open access at Springerlink.com

\begin{abstract}
The present study aims at defining the differential cytotoxicity effect of artemisinin toward P815 (murin mastocytoma) and BSR (kidney adenocarcinoma of hamster) cell lines. Cytotoxicity was measured by the growth inhibition using MTT assay. These in vitro cytotoxicity studies were complemented by the determination of apoptotic DNA fragmentation and Annexin V- streptavidin-FITC assay. Furthermore, we examined the in vitro synergism between artemisinin and the chemotherapeutic drug, vincristin. The in vivo study was investigated using the DBA2/P815 (H2d) mouse model. While artemisinin acted on both tumor cell lines, P815 was much more sensitive to this drug than BSR cells, as revealed by the respective $\mathrm{IC}_{50}$ values ( $12 \mu \mathrm{M}$ for P815 and $52 \mu \mathrm{M}$ for BSR cells). On another hand, and interestingly, apoptosis was induced in P815 but not induced in BSR. These data, reveal an interesting differential cytotoxic effect, suggesting the existence of different molecular interactions between artemisinin and the studied cell lines. In vivo, our results clearly showed that the oral administration of artemisinin inhibited solid tumor development. Our study demonstrates that artemisinin caused differential cytotoxic effects depending not only on the concentration and time of exposure but also on the target cells.
\end{abstract}

Keywords Artemisinin $\cdot$ Cytotoxicity $\cdot$ Apoptosis/necrosis $\cdot$ Synergism $\cdot$ Antitumor activity

\section{Introduction}

Artemisia annua L., a Chinese medicinal herb has evoked wide interest for its artemisinin content. This sesquiterpene lactone compound contains an endoperoxide bridge that forms a carbon-base free radical, when encountering an iron atom [1,2]. When formed, free intracellular radicals cause molecular damages and could lead to cell death.

\footnotetext{
M. Tilaoui · H. A. Mouse ( $\square)$ - A. Jaafari · A. Zyad Laboratory of Biological Engineering, Natural Substances, Cellular and Molecular Immuno-pharmacology, Immunobiology of Cancer Cells Cluster, Faculty of Science and Technology, P. Box 523, 23000 Béni-Mellal, Morocco

e-mail: h.aitmouse@usms.ma

A. Zyad

e-mail: ab.zyad2@gmail.com
}

The artemisinin molecule contains an endoperoxide bridge (-C-O-O-C-) that interacts with $\mathrm{Fe}(\mathrm{II})$ to form free radicals $[1,2]$. An intact endoperoxide is crucial, since artemisinin derivatives lacking an endoperoxide bridge are devoid of antimalarial activity [2, 3]. Unlike Fe(II), Fe(III) does not cause a reductive session of the endoperoxide. The reaction between artemisinin and $\mathrm{Fe}$ (III) is very slow, and the reaction products have been attributed to acid mediated heterolytic cleavage of the peroxide [4]. Because malaria parasites contain a high amount of $\mathrm{Fe}$ (II) in the form of heme molecules [5], artemisinin's anti-malarial bioactivity is due to its reaction with the intra-parasitic iron source and the generation of free radicals leading to cellular destruction $[2,6]$.

Due to their rapid rate of division, most cancer cells have high rates of iron intake [7] and express a high cell surface concentration of transferrin receptors [8], which are involved in the transport of iron into cells. In general, the aggressiveness of tumors is positively correlated with 


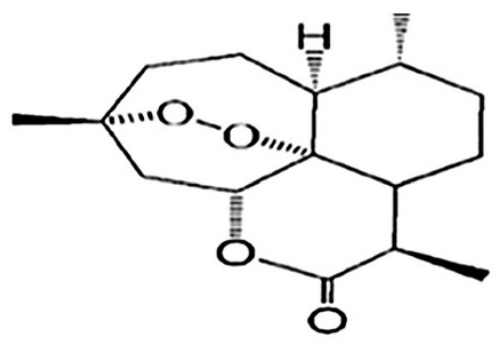

Fig. 1 Chemical structure of artemisinin

transferrin receptor concentration of its cells. Thus, artemisinin may be selectively toxic to cancer cells because of their high iron content. Also, normal cells pick up less iron and have better intracellular regulation of iron content. Then, they are significantly less susceptible to artemisinin.

Although these results need a confirmation to use different cell lines and although the molecular mechanisms need to be investigated, artemisinin has recently been suggested to have anticancer effects $[9,10]$.

In the present study, we report comparative data regarding the in vitro cytotoxic effect of artemisinin against tumor cell lines: P815 (murin mastocytoma) and BSR (kidney adenocarcinoma of hamster). Also, we investigate the synergistic interaction between artemisinin and vincristin against these cell lines. Furthermore, apoptosis induction in artemisinintreated cells is investigated (Fig. 1).

\section{Results}

\subsection{The Cytotoxicity of Artemisinin in P815 and BSR Cell Lines}

The in vitro cytotoxic activity was evaluated in P815 and BSR tumor cell lines. This activity is depending on the dose and time of exposure (Fig. 2).

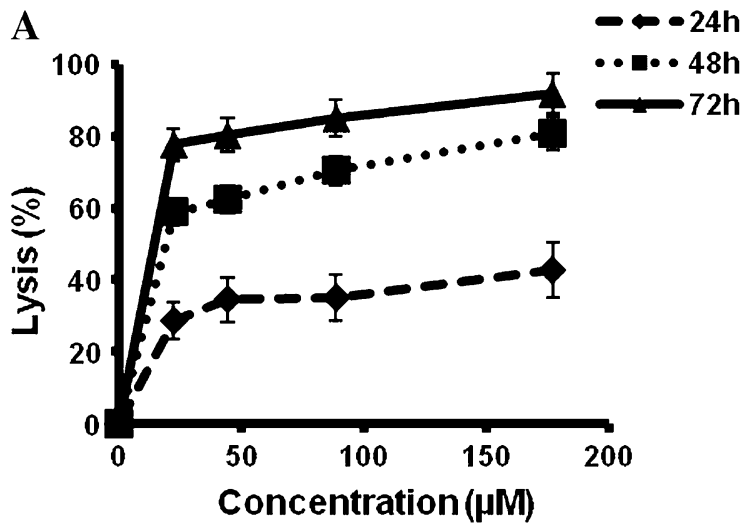

Fig. 2 Kinetics of the in vitro cytotoxicity of artemisinin in P815 and BSR cell lines. Cells (a P815 and b BSR) were treated with increasing concentrations of artemisinin. After 24, 48, and $72 \mathrm{~h}$ of incubation,

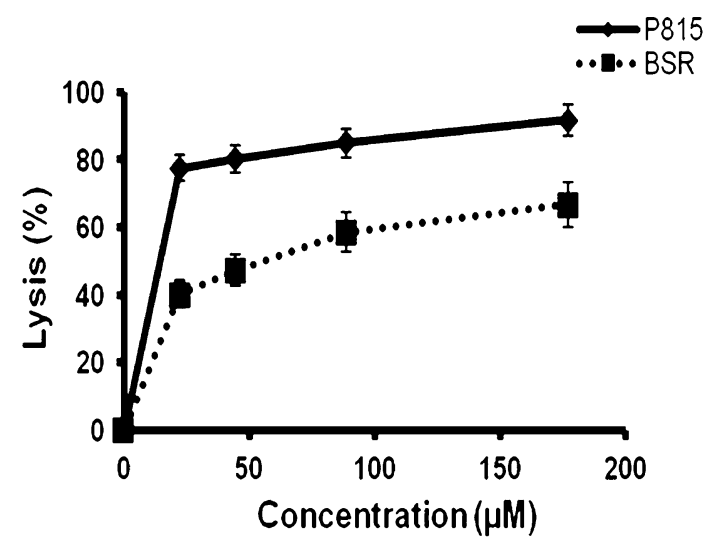

Fig. 3 In vitro cytotoxicity of artemisinin on tumor cell lines. Cells were treated with increasing concentrations of artemisinin. After $72 \mathrm{~h}$ of incubation, cytotoxicity was determined as described in Materials and methods. Each point represents the mean \pm SD of three independent experiments

The maximum cytotoxicity levels were obtained after an incubation time equal to $72 \mathrm{~h}$. Thus, in all the following experiments, the incubation time was fixed at $72 \mathrm{~h}$. The highest tested concentration had an acute cytotoxic effect reaching $90 \%$ proliferation inhibition in P815 cells and a partial effect (about $65 \%$ ) in BSR cells. These cell lines present different degrees of sensitivity to artemisinin. In fact, the concentrations leading to $50 \%$ cytotoxicity $\left(\mathrm{IC}_{50}\right)$ were about 12 and $52 \mu \mathrm{M}$ for P815 and BSR cell lines, respectively. The $\mathrm{IC}_{50}$ values indicate that the $\mathrm{P} 815$ cells are more sensitive to artemisinin treatment than the BSR cells (Fig. 3).

\subsection{Artemisinin Induced Apoptosis in P815 Cell Line}

The apoptotic DNA fragmentation was observed in P815 cells treated with $70 \mu \mathrm{M}$ of artemisinin for $24 \mathrm{~h}$ (Fig. 4,

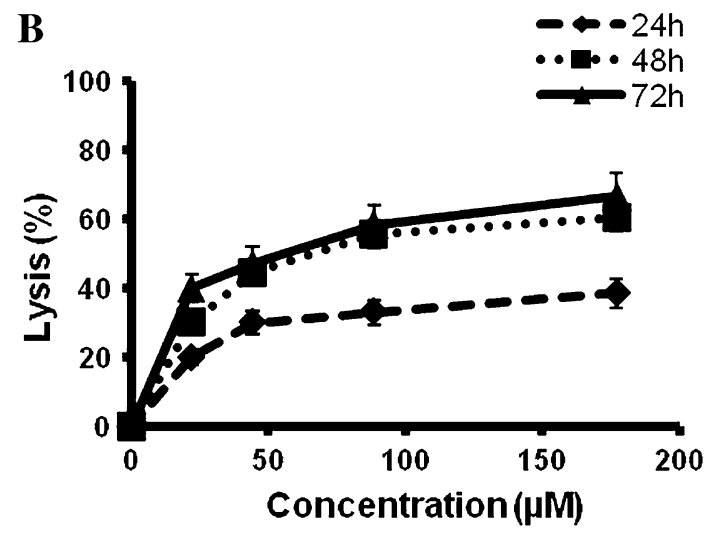

cytotoxicity was determined as described in Materials and methods. Each point represents the mean $\pm \mathrm{SD}$ of three independent experiments 


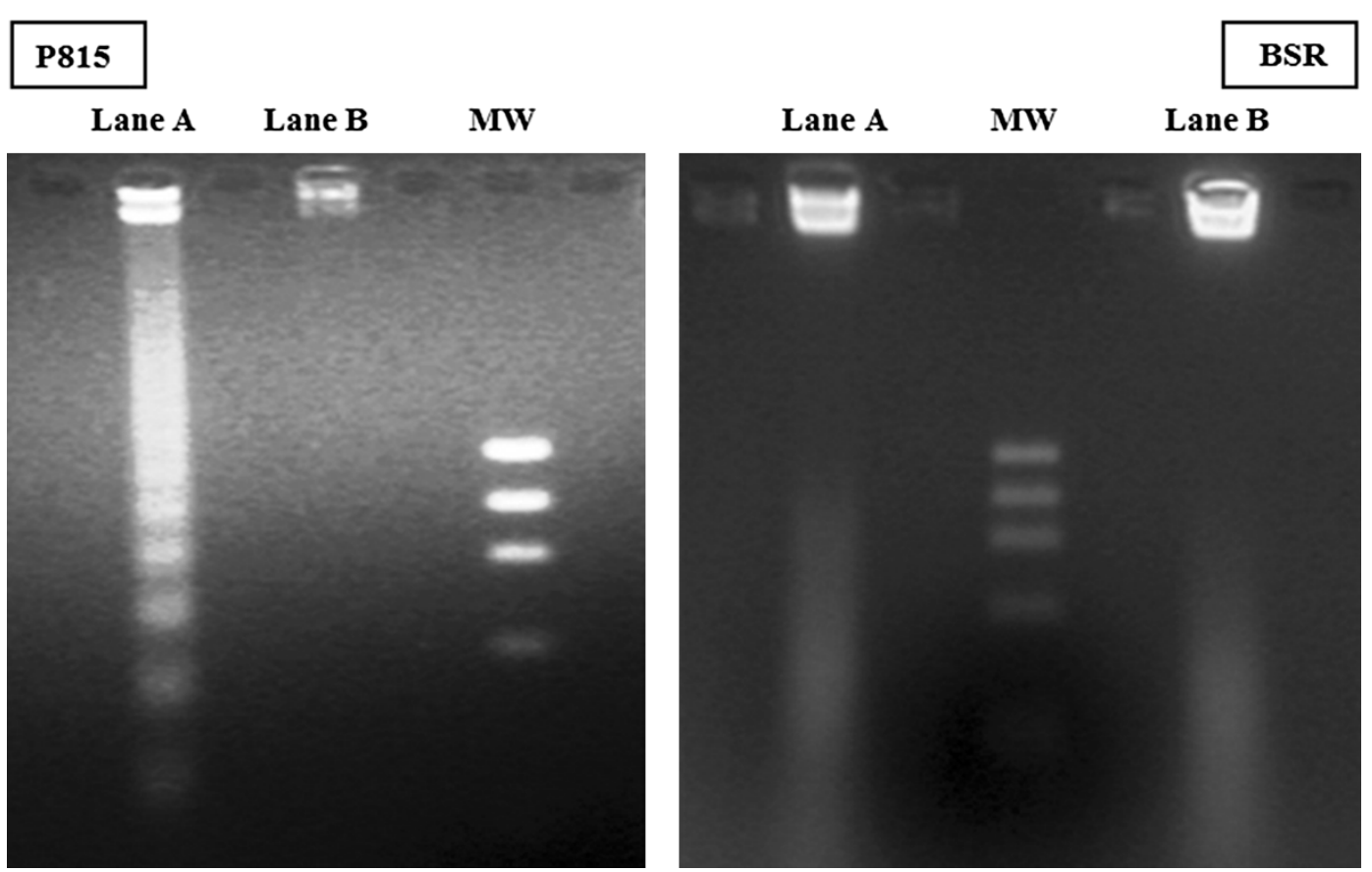

Fig. 4 Agarose gel electrophoresis demonstrating apoptotic DNA fragmentation in P815 cells treated with $70 \mu \mathrm{M}$ of artemisinin for 24 h. Lane $A$ treatment with artemesinin $70 \mu \mathrm{M}$; Lane $B$ control; $M W$ DNA marker treatment (180-200 bp)

lane A). Interestingly, at the same concentration $(70 \mu \mathrm{M})$, artemisinin did not induce DNA fragmentation in BSR cell line (Fig. 4, lane A).

\subsubsection{Apoptosis Detection by Annexin V- Streptavidin- FITC Staining}

Treatment with artemisinin $(70 \mu \mathrm{M})$ increased the percentage of annexin V positive cells in P815 cell lines (99.2 \pm $0.85 \%$ ). During the experiment, only $2.00 \pm 1.25 \%$ of the untreated P815 cells were annexin V-positive at $24 \mathrm{~h}$ (Fig. 5). On the other hand, BSR cells treated with artemisinin at $70 \mu \mathrm{M}$, showed a very low percentage of annexin $\mathrm{V}$ positive cells $(19 \pm 1.2 \%)$ compared to positive control ( $82 \pm 2 \%$ of positive annexin $\mathrm{V}$ cells). Furthermore, a size and volume increase is clearly observed in BSR cells treated with artemisinin but not in P815 cells (Fig. 5). These results indicate that the induction of apoptosis by artemisinin is a dependent target cell.

\subsection{Cytotoxic Effect of the Combination}

of Artemisinin and Vincristin on P815 and BSR

Cell Lines

In order to determine if artemisinin and vincristin combination display a synergistic cytotoxic activity against P815 and BSR cells, the combination index analysis (CI) method was used. For P815 cell line (Table 1), artemisinin concentration was fixed at the $\mathrm{IC}_{30}$ values $(3 \mu \mathrm{M})$ and vincristin concentration varied from 0.42 to $54 \mu \mathrm{M}$. Vincristin induced an additive effect at $13.5 \mu \mathrm{M}$ and an antagonistic effect at concentrations $<13.5 \mu \mathrm{M}$. Synergistic effect occurred for concentrations up to $27 \mu \mathrm{M}$ combined with artemisinin at dose of $3 \mu \mathrm{M}$.

Using the BSR cell line, the concentration of artemisinin was fixed at $10 \mu \mathrm{M}$ ( $\mathrm{IC}_{30}$ values) and the concentration of vincristin varied from 0.42 to $54 \mu \mathrm{M}$ (Table 2). At concentrations $<27 \mu \mathrm{M}$, the $\mathrm{CI}$ indicated an antagonistic interaction. However, when vincristin was added at increasing concentrations starting from $27 \mu \mathrm{M}$, the resulting interaction was nearly additive.

\subsection{Effect of Artemisinin on Tumor Growth in Mice}

In order to evaluate if our in vitro results have a clinical relevance, artemisinin was used for in vivo assays using DBA2/P815 $\left(\mathrm{H}^{\mathrm{d}}{ }^{\mathrm{d}}\right)$ mouse model. As shown in Fig. 6, at day zero of treatment the tumor volume was about $0.2 \pm 0.06 \mathrm{~cm}^{3}$ for all groups tested $(P<0.05)$.

The tumor volume increase linearly and significantly in control mice between day 0 and day 6 to reach $1.7 \pm 0.08 \mathrm{~cm}^{3}$ compared to the treated animals $\left(1 \pm 0.08 \mathrm{~cm}^{3}\right)$. After the 6th day, tumor volumes of untreated mice continue to growth, which reached at day 20 a mean volume of $2.2 \pm 0.1 \mathrm{~cm}^{3}$. Thus, tumor-bearing mice died from progressive tumors. However, in treated animals, tumor volume began to decrease to attaint $0.26 \pm 0.06 \mathrm{~cm}^{3}$ at day 10 , and close to regression $\left(0.003 \pm 0.06 \mathrm{~cm}^{3}\right)$ at day 


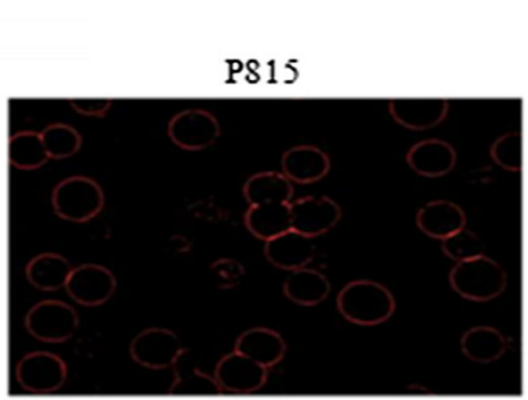

\section{Untreated cells}

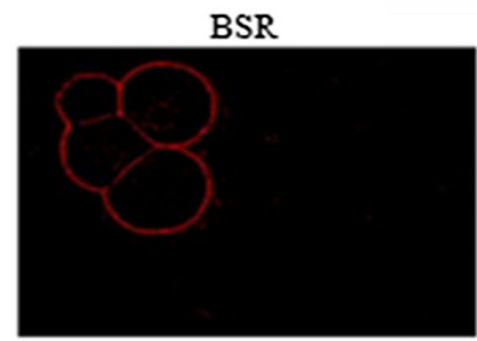

A

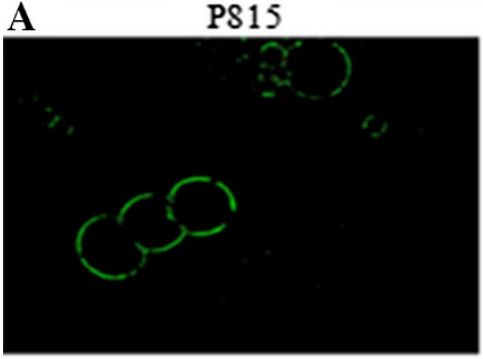

Artemisinin treated cells

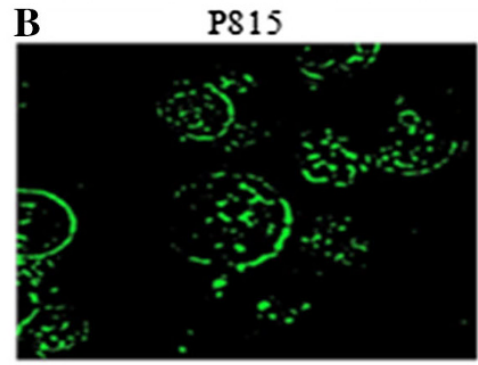

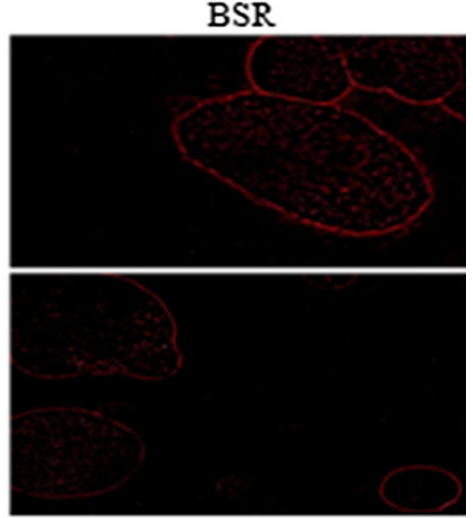

\section{Positive control}

PS15

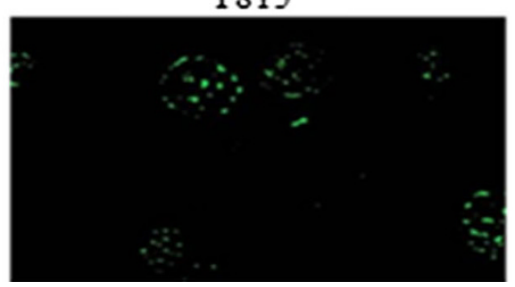

Fig. 5 Apoptosis induction following treatment of P815 and BSR cells with artemisinin $(70 \mu \mathrm{M})$. Untreated cells or artemisinin treatedcells were mixed with annexin V-biotin and treated sequentially with streptavidin conjugated to FITC as described in materials and

14. This difference was found to be significant between the control and treated groups $(P<0.05)$. The tumor volumes of treated animals remained constant between the 14th and 20th day, suggesting an inhibition of cell growth during this period. Our results, demonstrate that the oral administration of artemisinin reduced significantly solid tumor volume in the treated groups compared to the negative control $(P<0.05)$. In addition to increasing life span, treating tumor-bearing animals with artemisinin caused a considerable decrease in mortality percentage in comparison to nontreated tumor-bearing animals (data not shown).

Tumors were induced in DBA2 mice and treated using the protocol described in experimental section. Statistical differences between experimental groups were assessed by analysis of variance (ANOVA), with the level of significance set at $P<0.05$.

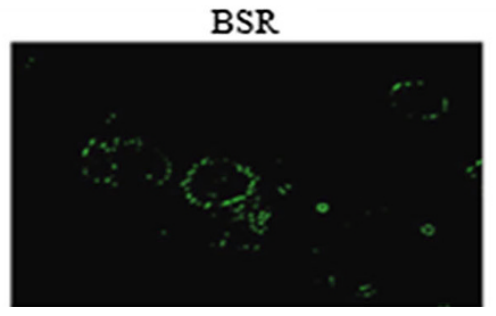

methods. Cells were visualized with a microscope equipped with fluorescence filter. a early apoptotic cells, b advanced apoptotic cells. Positive control: cells cultured under conditions of serum starvation

\subsection{Effect of Artemisinin on Human Peripheral Blood Mononuclear Cells (PBMC)}

Knowing that the majority of clinically approved anticancer drugs are characterized by a narrow therapeutic window, that results mainly from a high systemic toxicity of the drugs. Thus, we tested artemisinin against the human peripheral blood mononuclear cells (PBMC), in order to determine their effects against normal cells. The results obtained are represented in Fig. 7, It is depicted that artemisinin which shows that at a concentrations able to induce a cytotoxic activity against tumor cells (P815 and BSR), no cytotoxicity effect on normal cells was observed.

PBMC were prepared from human normal donors by Ficoll-hypaque density centrifugation. Cells were incubated in 96-well microtiter plates in the presence of 
Table 1 CI analysis of vincristin with $3 \mu \mathrm{M}$ of artemisinin in P815 cells

\begin{tabular}{lllll}
\hline $\begin{array}{l}\text { Vincristin } \\
(\mu \mathrm{M})\end{array}$ & $\begin{array}{l}\text { Artemisinin } \\
(\mu \mathrm{M})\end{array}$ & $\mathrm{Fa}(\mathrm{A}+\mathrm{V})$ & $\mathrm{CI}$ & Description $^{\mathrm{a}}$ \\
\hline 54 & 3 & 1 & 0.59 & Synergy \\
27 & 3 & 1 & 0.78 & Synergy \\
13.5 & 3 & 0.99 & 1.32 & Slight additive \\
6.75 & 3 & 0.92 & 1.95 & Antagonism \\
3.37 & 3 & 0.76 & 1.82 & Antagonism \\
1.68 & 3 & 0.73 & 2.20 & Antagonism \\
0.84 & 3 & 0.69 & 3.82 & Antagonism \\
0.42 & 3 & 0.68 & 4.83 & Antagonism \\
\hline
\end{tabular}

$F a$ affected fraction, $A$ artemisinin, $V$ vincristin, $C I$ combination index

${ }^{\mathrm{a}} \mathrm{CI}=1.00$, additive effect; $\mathrm{CI}<1.00$, synergistic effect; $\mathrm{CI}>1$, antagonistic effect

Table 2 CI analysis of vincristin with $10 \mu \mathrm{M}$ of artemisinin in BSR cells

\begin{tabular}{lllll}
\hline $\begin{array}{l}\text { Vincristin } \\
(\mu \mathrm{M})\end{array}$ & $\begin{array}{l}\text { Artemesinin } \\
(\mu \mathrm{M})\end{array}$ & $\begin{array}{l}\mathrm{Fa} \\
(\mathrm{A}+\mathrm{V})\end{array}$ & $\mathrm{CI}$ & Description $^{\mathrm{a}}$ \\
\hline 54 & 10 & 0.93 & 1.15 & Nearly additive \\
27 & 10 & 0.89 & 1.3 & Nearly additive \\
13.5 & 10 & 0.86 & 1.4 & Antagonism \\
6.75 & 10 & 0.83 & 1.935 & Antagonism \\
3.37 & 10 & 0.81 & 2.94 & Antagonism \\
1.68 & 10 & 0.80 & 4.605 & Antagonism \\
0.84 & 10 & 0.80 & 7.89 & Antagonism \\
0.42 & 10 & 0.76 & 9.945 & Antagonism \\
\hline
\end{tabular}

$F a$ affected fraction, $A$ artemisinin, $V$ vincristin, $C I$ combination index

${ }^{\mathrm{a}} \mathrm{CI}=1.00$, additive effect; $\mathrm{CI}<1.00$, synergistic effect; $\mathrm{CI}>1$, antagonistic effect

different concentrations of artemisinin $(0-177 \mu \mathrm{M})$. After $48 \mathrm{~h}$ incubation, viability was determined using MTT assay as described in materials and methods. Data are mean $\pm \mathrm{SD}$ of three experiments in duplicate.

\section{Discussion}

In this paper, the in vitro antiproliferation activities of artemisinin were tested on the murin mastocytoma cell line (P815) and the kidney adinocarcinoma cell line of hamster (BSR). These activities were found to be time and dose dependent. Other investigations led to this conclusion when artemisinin cytotoxicity has been tested on the H69 human small-cell lung carcinoma (SCLC) [11].

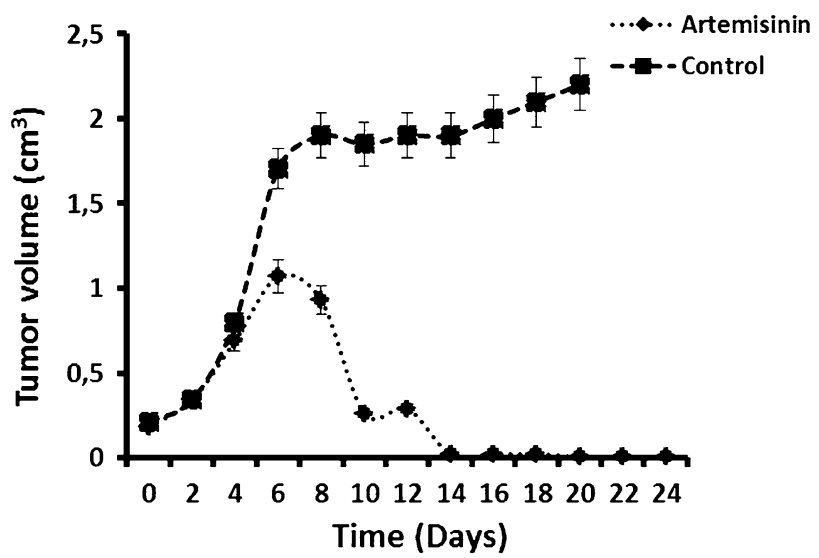

Fig. 6 Effect of artemisinin on the evolution of tumor volume in mice

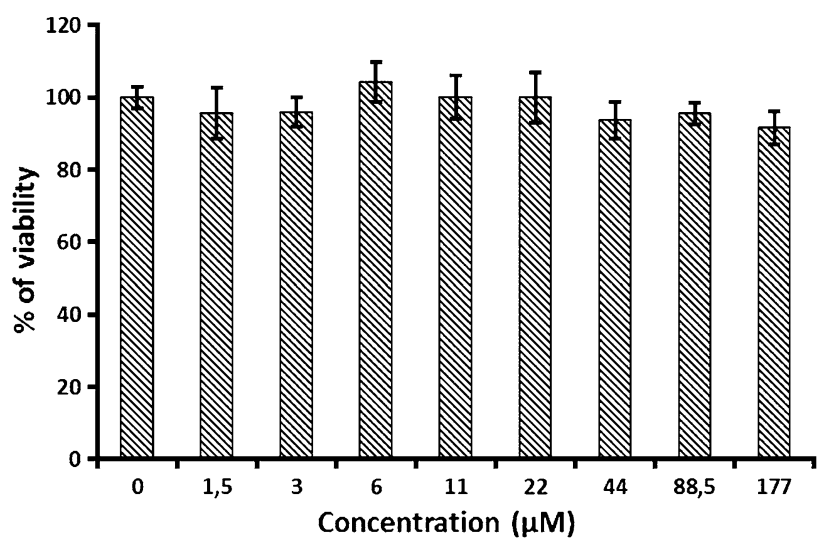

Fig. 7 Effect of artemisinin against the PBMC

On the other hand, we report differential cytotoxic properties of artemisinin as shown in Fig. 2. In fact, the kinetics of cytotoxicity and the $\mathrm{IC}_{50}$ values were dependent on the target cells. Compared to BSR cells, the P815 cell line was more sensitive to the cytotoxic activity of artemisinin $\left(\mathrm{IC}_{50}=12 \mu \mathrm{M}\right.$ vs $\mathrm{IC}_{50}=52 \mu \mathrm{M}$, respectively). Indeed the leukemic cells normally contain excess iron in their cytoplasm and the reactivity of artemisinin is enhanced by iron ions. Interestingly, normal human lymphocytes presented a weak sensitivity to artemisinin [12].

At the molecular level, artemisinins are initially activated by the cleavage of the endoperoxide with intracellular heme-iron [5, 13]. The subsequent biochemical events and cellular target(s) of artemisinin, however, remain unclear. It has been proposed that the transfer of an oxygen atom from the peroxide group of artemisinin to the chelated iron generates a $\mathrm{Fe}(\mathrm{IV})=\mathrm{O}$ species $[13,14]$. The resulting free radical intermediate may kill the target by alkylating and damaging cell proteins $[13,15]$. 
In the present work, using two different methods, we conclude that artemisinin induced apoptosis in P815 cells and not in BSR cells. In fact, apoptotic DNA fragments were detected in agarose gel electrophoresis when P815 cells were used as target (Fig. 4). On the contrary, no apoptotic DNA fragmentation was observed in the BSR cells. These results were confirmed by Annexin V-binding assays (Fig. 5). Phosphatidylserine externalization was assessed by observing at fluorescence microscopy the extent of streptavidin-fluorescein isothiocyanate (FITC) annexin- $\mathrm{V}$ binding. In fact, a high percentage of annexin $\mathrm{V}$ positive cells was detected in P815 cells (99.2\%) but in BSR cells, there was only a poor percentage of positive cells $(19 \%)$. Interestingly, an increase in the size of artemisinin-treated BSR cells was observed. This increase is a characteristic of necrotic cell death pathway [16].

The ability of artemisinin to induce apoptosis in P815 cells is in agreement with other results reporting that artemisinin and derivatives induce apoptosis in cancer cells $[17,18]$. This effect may occur during the G1 phase of the cell cycle [19]. This is understandable since enhanced transferrin receptor expression and increased iron uptake occur during this phase.

On the other hand, the evaluation of synergy or antagonism of agents used in combination is an integral part of cancer chemotherapy development. In this paper, we examined the synergistic effect of artemisinin combined with the anticancer drug vincristin, an inhibitor of cell microtubule integrity and therefore inhibitor of nucleospindle formation in cell division. This assay was conducted using the Chou and Talalay method [20]. These two drugs exhibited pronounced in vitro cytotoxicity when used alone against P815 and BSR cells. The synergism of vincristin $(54$ and $27 \mu \mathrm{M})$ with artemisinin at the $\mathrm{IC}_{30}$ values $(3 \mu \mathrm{M})$ was observed in P815 cells. However, the antagonistic effect was shown at lower doses of vincristin. Regarding BSR cells, the interaction between vincristin (54 and $27 \mu \mathrm{M}$ ) with artemisinin at the fixed concentration of $\mathrm{IC}_{30}$ values $(10 \mu \mathrm{M})$ is nearly additive; nevertheless, below the dose of $27 \mu \mathrm{M}$ of vincristin, the antagonism occurred. The interaction between vincristin and artemisinin has not been described in the literature. To our knowledge, this is the first data about the interaction of artemisinin and vincristin; however we postulate that these results may reveal the existence of differential mechanism(s) of vincristin and artemisinin interactions in P815 and BSR cells. Furthermore, these results may have a pharmacological relevance because an anticancer drug may produce antiproliferation at low concentrations and cell death at high concentrations [21].

To find out any clinical relevance, in vivo artemisinin assays were performed in the $\mathrm{DBA}_{2} / \mathrm{P} 815\left(\mathrm{H}^{2}{ }^{\mathrm{d}}\right)$ tumor bearing mice. We report that a regression of tumor volume was observed in artemisinin treated mice (Fig. 6). The antitumor activity of artemisinin is poorly described in the literature, although other authors have reported that daily oral intake of artemisinin could prevent or delay the development of breast cancer in the rat [10]. Indeed artemisinin decreased the number and size of tumors experimentally induced by the carcinogen (7,12-dimethylbenz[a]anthracene). Recently, Chen et al. established that dihydroartemisinin, a derivative of artemisinin, inhibited ovarian cancer cell growth in mice. In fact, at doses of 10 and $25 \mathrm{mg} / \mathrm{kg}$ respectively, this molecule resulted in 24 and $41 \%$ tumor growth inhibition as compared to control mice, in the A2780 xenograft tumor model $(P<0.05)$, and respectively 14 and $37 \%$ tumor growth inhibition in the OVCAR-3 model $(P<0.05)$ [22]. Furthermore, artesunate, another derivative of artemisinin, was proved to decrease tumor microvessel density and subsequently reduced tumor growth with no apparent toxicity to the animals at 50 and $100 \mathrm{mg} / \mathrm{kg} / \mathrm{day}$, respectively. The authors described the anti-angiogenic effect of artemisinin analogues [23-25]. Recently, Steglich et al. [26] have indicated that two artemisinin derivatives, SM616 and GHP-AJM-3/23, could be a promising P-glycoprotein inhibitor to treat cancer therapy [26].

Artemisinin may affect cancer development and growth via various mechanisms. A possible mechanism is that it selectively kills pre-cancerous cells. Artemisinin reacts with iron to form free radicals that kill cells. Various studies have suggested the involvement of iron in the development of pre-cancerous lesions. For example, iron accumulation preceded tumor formation in polycholinated biphenyl-induced liver tumor [27].

\section{Conclusion}

In conclusion, our study demonstrates that artemisinin causes differential cytotoxic effects depending not only on the concentration and time of exposure but also on the target cells. We reported for the first time that artemisinin may induce apoptotic cell lysis depending on cancer cell type. Furthermore, we reported that the oral administration of artemisinin significantly inhibited the tumor growth of P815 in DBA2 mice. This activity was associated with an increase in life span (data not shown). On the other hand, this is the first report on the in vitro interaction between artemisinin and vincristin. Our study provides a basis for future clinical studies of artemisinin in patients with cancer, used alone or in combination with conventional anticancer drugs. An adjuvant mechanism-based therapy with artemisinin compounds may significantly improve clinical efficacy.

This research, together with the previously reported findings, will help improve our understanding about the 
molecular mechanisms of artemisinin and its derivatives as anticancer agents.

\section{Experimental Section}

\subsection{Cell Culture}

The cell lines (P815 and BSR) were cultured in Dulbecco's modified Eagle's medium (DMEM medium supplemented with $5 \%$ heat-inactivated fetal calf serum (Gibco BRL, Cergy Pontoise, France), supplemented with penicillin G-streptomycin (1\%), and $0.2 \%$ sodium bicarbonate (Sigma). Incubation was performed at $37{ }^{\circ} \mathrm{C}$ in a humidified atmosphere containing $5 \% \mathrm{CO}_{2}$.

\subsection{Cell Growth Inhibition Assay}

BSR and P815 cell lines were harvested from starting cultures at the exponential growth phase. After a PBS wash, the harvested cells were poured in flat-bottomed 96well microtiter plates containing $100 \mu \mathrm{L}$ of complete medium per well $\left(5 \times 10^{4}\right.$ cells $\left./ \mathrm{ml}\right)$. $3 \mathrm{~h}$ later, several dilutions starting from the concentration $100 \mu \mathrm{M}$ artemisinin in DMSO completed to $100 \mu \mathrm{L}$ with complete DMEM medium were then added. Control cells were treated with DMSO alone. In all cases DMSO final concentration never exceeded $2 \%$. After $48 \mathrm{~h}$ incubation in a humidified atmosphere at $37{ }^{\circ} \mathrm{C}$ and $5 \% \mathrm{CO}_{2}, 100 \mu \mathrm{L}$ of medium was carefully removed from each well and replaced with $20 \mu \mathrm{L}$ MTT solution ( $5 \mathrm{mg} / \mathrm{mL}$ PBS). After $4 \mathrm{~h}$ incubation under the same conditions, the cleavage of MTT to formazan by metabolically active cells was quantified by scanning the plates at $540 \mathrm{~nm}$ using a Multiskan EX (Finland) apparatus. Three independent sets of experiments performed in duplicate were evaluated. The relative inhibition of cell proliferation was calculated by the formula:

$\%$ inhibition $=100 \times\left(1-\mathrm{A} / \mathrm{A}_{\mathrm{O}}\right)$,

where $\mathrm{A}_{\mathrm{O}}$ and $\mathrm{A}$ are the absorbencies of negative control and artemisinin-treated cells, respectively.

The cytotoxic effect of artemisinin against the two cell lines was compared using the $\mathrm{IC}_{50}$ values (artemisinin concentration leading to $50 \%$ inhibition of cell viability).

\subsection{Kinetic Study}

The cytotoxic effect of artemisinin against P815 and BSR cells was evaluated after 24, 48 and $72 \mathrm{~h}$, using the MTT test in the same conditions described above.

\subsection{Apoptosis Assay}

\subsubsection{Fragmented DNA Electrophoresis}

P815 and BSR cells $\left(5 \times 10^{6}\right.$ cells $)$ were treated with artemisinin $(70 \mu \mathrm{M})$. After $12 \mathrm{~h}$ incubation in the same conditions described for cell culture, the cells were washed in PBS and treated with the lysis buffer (100 mM TRIS, $0.5 \mathrm{M}$ EDTA, $10 \% \mathrm{SDS}, 5 \mathrm{M} \mathrm{NaCl}$ and $20 \mathrm{mg} / \mathrm{mL}$ Proteinase K). Samples were then incubated at $37{ }^{\circ} \mathrm{C}$ for $3 \mathrm{~h}$ with agitation. Then, DNA was precipitated by ispropanol and was recovered and dispersed in prelabelled Eppendorf in $10 \mathrm{mM}$ Tris $\mathrm{HCl}, 0.1 \mathrm{mM}$ EDTA, $\mathrm{pH} 7.5$ solution. The samples of dissolved DNA were subjected to electrophoresis at $25 \mathrm{~V}$ for $8 \mathrm{~h}$ in $2 \%$ (w/v) agarose gels complemented with ethidium bromide $(1 \mathrm{mg} / \mathrm{mL})$. Ethidium bromide-stained bands showing DNA fragmentation (180-200 bp) provide confirmation of programmed cell death. The molecular weight marker used was the $\lambda$ Hae III $\varphi X$ 147. Separated DNA fragments (DNA ladders) were visualized using a UV trans-illuminator (310 nm).

\subsubsection{Anexin V Biotin-Streptavidin FITC Test}

To further confirm the apoptotic changes in P815 and BSR cells, Anexin V biotin-streptavidin FITC-stained cells were visualized with a microscope equipped with fluorescence filter (OLYMPUS OM52). Briefly, P815 and BSR cells treated with $70 \mu \mathrm{M}$ of artemisinin or grown under conditions of serum starvation (served as a positive control) for $24 \mathrm{~h}$ were collected in a $15 \mathrm{~mL}$ centrifuge tube. After a wash in PBS, cells were stained with annexin V-biotin and treated sequentially with streptavidin conjugated to FITC. The assay is based on the ability of annexin V (green fluorescence) to bind to the phosphatidylserine exposed on the surface of cells undergoing apoptosis.

\subsection{Synergistic Studies}

The degree of synergism between artemisinin and vincristin was determined by using $\mathrm{CI}$ analysis at a non-constant ratio, i.e., drug combinations were made by varying the concentrations of one drug (vincristin) while keeping the second drug (artemisinin) concentration fixed at $\mathrm{IC}_{30}$. An average $\mathrm{CI}<1$ indicates synergism, $\mathrm{CI}>1$ indicates antagonism and an average $\mathrm{CI}=1$ indicates additivity [20].

\subsection{In Vivo Antitumor Effect of Artemisinin}

DBA2 mice (H2d haplotype), purchased from the animal breeding center of Orleans (France), were maintained under specific pathogen-free conditions on a $12 \mathrm{~h}$ lightdark cycle. Mice were provided with sterile food and water 
ad libitum and were used at 6-8 weeks of age with an average weight of 20-24 g. All animal experiments were performed according to national regulations which are comparable to the accepted principles for laboratory animal use and care of the European Community guidelines.

Aliquots of P815 cells $\left(\sim 10^{7}\right.$ cells $\left./ \mathrm{mL}\right)$ were injected subcutaneously into the left inguinal area of mice. The tumor growth and body weight of each mouse were monitored every day. Tumor volume was determined as TV $\left(\mathrm{cm}^{3}\right)=\mathrm{L} \times \mathrm{W}^{2} / 2$, where "L" is the tumor length and "W" the tumor width [28]. Mice bearing palpable tumors were randomly divided into treatment and control groups ( $n=6 \mathrm{mice} /$ group). Artemisinin, dissolved in vegetable oil, was administered to mice of the treated group via oral route (gavage) at a dose of $80 \mathrm{mg} / \mathrm{kg}$ in a final volume of $100 \mu \mathrm{L}$. This quantity was administrated to mice at days 0 , 2, 4, 6, 8, 10 (one oral administration every $48 \mathrm{~h}$, six times). Each mice of the control group received $100 \mu \mathrm{L} /$ 2 days vegetal oil only (at the same dates as for artemisinin-treated mice). Assays were conducted in triplicate.

\subsection{Effect of Artemisinin on Human Peripheral Blood Mononuclear Cells (PBMC)}

This test was realised in order to evaluate the effect of artemisinin on human normal cells using the MTT colorimetric assay described above. To isolate the PBMC, blood samples were collected from healthy human donors in heparinized tubes and the PBMC were isolated using standard Ficoll-hypaque density centrifugation. The interface lymphocytes were washed twice with phosphate-buffered solution (PBS). Cells were incubated in 96-well microtiter plates in the presence of different concentrations of artemisinin $(0-177 \mu \mathrm{M})$.

\subsection{Statistical Analysis}

The individual data values are presented as the arithmetic mean \pm SD (standard deviation). The statistical significance of the results obtained from in vitro studies was evaluated by the Student's $t$ test or by ANOVA at $P<0.05$, using STATISTICA software.

Acknowledgments The authors would like to thank Prof. Zacharie Brahmi (The Children's Hospital of Indianapolis, USA), for having reviewed the manuscript. The work was funded by a grant from the CNRST (PROTARSIII, D61/07), Rabat, Morocco.

Conflict of interest The authors declare no conflict of interest.

Open Access This article is distributed under the terms of the Creative Commons Attribution License which permits any use, distribution, and reproduction in any medium, provided the original author(s) and the source are credited.

\section{References}

1. P.J. Rosenthal, S.R. Meshnick, Mol. Biochem. Parasitol. 83, 131-139 (1996)

2. V. Dhingra, K.V. Rao, M.L. Narasu, Life Sci. 66, 279-300 (1999)

3. J. Heisler, L. Elvir, F. Barnouti, E. Charles, T.D. Wolkow, R. Pyati, Nat. Prod. Bioprospect. 4, 1-9 (2014)

4. D.J. Creek, F.C. Chiu, R.J. Prankerd, S.A. Charman, W.N. Charman, J. Pharm. Sci. 94, 1820-1829 (2005)

5. J. Wiesner, R. Ortmann, H. Jomaa, M. Schlitzer, Angew. Chem. Int. Ed. 42, 5274-5293 (2003)

6. S.R. Meshnick, T.W. Tsang, F.B. Lin, H.Z. Pan, C.N. Chang, F. Kuypers, D. Chiu, B. Lubin, J.W. Eaton, G.J. Brewer, in Malaria and the red cell: 2. Proceedings of the second workshop on malaria and the red cell, Ann Arbor, 24, Oct 1988 (Alan R. Liss, Inc., 1989), pp. 95-104

7. M. Karin, B. Mintz, J. Biol. Chem. 256, 3245-3252 (1981)

8. M. Kawamoto, T. Horibe, M. Kohno, K. Kawakami, BMC Cancer 11, 359 (2011)

9. N.P. Singh, H. Lai, Life Sci. 70, 49-56 (2001)

10. H. Lai, N.P. Singh, Cancer Lett. 231, $43-48$ (2006)

11. D. Sadava, T. Phillips, C. Lin, S.E. Kane, Cancer Lett. 179, 151-156 (2002)

12. H. Lai, N.P. Singh, Cancer Lett. 91, 41-46 (1995)

13. P.M. O'Neill, V.E. Barton, S.A. Ward, Mol. Basel Switz. 15, 1705-1721 (2010)

14. G.H. Posner, J.N. Cumming, P. Ploypradith, C.H. Oh, J. Am. Chem. Soc. 117, 5885-5886 (1995)

15. P. Zhu, B.M.K. Tong, R. Wang, J.P. Chen, S. Foo, H.C. Chong, X.L. Wang, G.Y. Ang, S. Chiba, N.S. Tan, Cell Death Dis. 4, e552 (2013)

16. E. Healy, M. Dempsey, C. Lally, M.P. Ryan, Kidney Int. 54, 1955-1966 (1998)

17. N.P. Singh, H.C. Lai, Anticancer Res. 24, 2277-2280 (2004)

18. A.E. Mercer, J.L. Maggs, X.M. Sun, G.M. Cohen, J. Chadwick, P.M. O'Neill, B.K. Park, J. Biol. Chem. 282, 9372-9382 (2007)

19. Y. Li, F. Shan, J.M. Wu, G.S. Wu, J. Ding, D. Xiao, W.Y. Yang, G. Atassi, S. Léonce, D.H. Caignard, Bioorg. Med. Chem. Lett. 11, 5-8 (2001)

20. T.C. Chou, P. Talalay, Adv. Enzym. Regul. 22, $27-55$ (1984)

21. L. Zhao, M.G. Wientjes, J.L. Au, Clin. Cancer Res. 10, 7994-8004 (2004)

22. T. Chen, M. Li, R. Zhang, H. Wang, J. Cell Mol. Med. 13, 1358-1370 (2009)

23. H.H. Chen, H.J. Zhou, G.D. Wu, X.E. Lou, Pharmacology 71, 1-9 (2004)

24. H.H. Chen, H.J. Zhou, X. Fang, Pharmacol. Res. 48, 231-236 (2003)

25. H.C. Lai, N.P. Singh, T. Sasaki, Invest. New Drugs 31, 230-246 (2013)

26. B. Steglich, A. Mahringer, Y. Li, G.H. Posner, G. Fricker, T. Efferth, Nat. Prod. Bioprospect. 2, 59-64 (2012)

27. J. Whysner, C.X. Wang, Toxicol. Sci. 62, 36-45 (2001)

28. T. Yoshikawa, S. Kokura, K. Tainaka, Y. Naito, M. Kondo, Cancer Res. 55, 1617-1620 (1995) 